\title{
Influence of ultra-high strength concrete on circular concrete-filled
}

\section{dual steel columns}

\author{
M. L. Romero ${ }^{a}{ }^{*}$, C. Ibañez ${ }^{b}$, A. Espinos ${ }^{a}$, J.M. Portolés ${ }^{b}$ and A. Hospitaler ${ }^{a}$ \\ ${ }^{a}$ Instituto de Ciencia y Tecnología del Hormigón (ICITECH), \\ Universitat Politècnica de València, Valencia, Spain \\ ${ }^{b}$ Department of Mechanical Engineering and Construction, \\ Universitat Jaume I, Castellón, Spain \\ * Corresponding author. e-mail address: mromero@mes.upv.es
}

\begin{abstract}
This paper presents the results of an experimental program where the load-bearing capacity at room temperature of 14 slender circular concrete-filled dual steel tubular (CFDST) columns under axial load was analysed. In this study, two specimens were prepared as ordinary concrete-filled steel tubular (CFST) columns to be used as references to evaluate the mechanical contribution of the inner steel tube and its infill in the CFDST columns. In addition, the effect of two types of concrete: normal strength concrete (NSC) and ultra-high strength concrete (UHSC) was assessed. Besides, in order to study the influence of the steel share between the inner and outer tube, different cross-sectional configurations were considered. Since the number of experimental results available in the literature on slender CFDST columns is scarce, this work provides novel results to this research field. The different influence of the steel distribution in the response of the specimens of each series was observed, with no influence in the case of columns with ultra-high strength concrete in the outer ring. Finally, the current provisions of Eurocode 4 for the design of composite columns were assessed by means of the results of these tests, being necessary more test data to extract solid conclusions about their accuracy and reliability.
\end{abstract}


Keywords: Concrete- filled steel tubular column, concrete contribution ratio, double-tube, ultra-high strength concrete, Eurocode 4.

\section{NOTATION}

CHS Circular hollow section

SHS Square hollow section

CFDST Concrete-filled dual steel tube

CFST Concrete-filled steel tube

D Diameter of the steel tube

$t \quad$ Thickness of the steel tube

$e \quad$ Eccentricity

,ext Relating to the outer steel tube

, int Relating to the inner steel tube

$f_{\mathrm{c}} \quad$ Compressive cylinder strength of concrete (test date)

$f_{\mathrm{s}} \quad$ Yield strength of reinforcing steel

$f_{\mathrm{y}} \quad$ Yield strength of structural steel

EC4 Eurocode 4

HSC High strength concrete

$M_{b, R d} \quad$ Design buckling resistance moment

$M_{p l, N e d} \quad$ Plastic bending resistance of the section

$N_{u} \quad$ Ultimate axial load from tests

$N_{b, R d} \quad$ Design axial buckling load from EC4 Part 1.1

UHSC Ultra-high strength concrete

$\bar{\lambda} \quad$ Relative slenderness $\bar{\lambda}=\sqrt{N_{p l} / N_{c r}}=\sqrt{\left(A_{c} f_{c}+A_{a} f_{y}+A_{s} f_{s}\right) /\left[\left(\pi^{2} E I\right) / L^{2}\right]}$ 
Romero ML, Ibañez C, Espinos A, Portolés JM, Hospitaler A. Influence of ultra-high strength concrete on circular concretefilled dual steel columns. 2017. Structures; 3: 13-20.

doi: 10.1016/j.istruc.2016.07.001

L $\quad$ Column length 


\section{INTRODUCTION}

Among the uses of concrete-filled steel tubular (CFST) columns, the construction of high-rise buildings and bridge piers are two of the most common applications and, in these situations, these members are subjected to considerably high compression axial loads. Therefore, together with the increase in the usage of CFT columns, the employment of high strength concrete (HSC) and even ultra-high strength concrete (UHSC) in this type of composite columns is becoming popular given their capacity of improving the load-bearing capacity of the member with a reduced technological cost. However, the application of high strength materials results in an increment in the member slenderness due to the reduction of the strictly needed net cross-sectional area of the composite column. As a consequence, new buckling problems arise which negatively affect the structural response of the column, especially in the fire situation.

With the aim of reducing these drawbacks, in the last years new innovative configurations have appeared based on the same technology of combining hollow steel tubes and concrete. This is the case of concrete-filled dual steel tubular (CFDST) columns where an extra inner tube is placed concentrically as shown in Fig. 1. Among CFDST columns, two variants can be found: double-skin members (Fig. 1a), where the inner tube is empty, and those known as double-tube members (Fig. 1b), where concrete is also poured into the inner steel tube.

Thus, for the same load-bearing capacity, CFDST columns are not only able to maintain but also to improve the numerous positive attributes that CFST columns already have at ambient temperature but with lighter self-weight.

With regard to the structural behaviour at high temperature, this novel type of crosssection can be designed to solve some of the buckling related disadvantages presented above since the existence of an inner steel tube at a lower temperature can contribute to counteract 
the second order effects in slender columns. Besides, the double-tube configuration allows placing concrete of different grades at the inner core and at the outer ring respectively. This versatility can help to relieve spalling problems which are directly related to the employment of UHSC if it is poured in those parts of the column at lower temperature which, in turn, increases the UHSC effectiveness.

Most of the experimental works performed to characterize CFDST sections have focused on stub columns with double-skin sections. In this line, the main contributions can be found in published works [1], [2], [3], [4] and [5]. Thus, Zhao and Grzebieta [1] and Elchalakani et al. [4] carried out experimental campaigns on stub columns with SHS-SHS and CHS-SHS respectively. In both campaigns the outer steel tube was thicker than the inner one (thick-thin) and the concrete of the outer ring had a compressive strength of 60-64 MPa. In spite of this, experimental results were compared with predictions given by Eurocode 4 Part 1-1 [6], although code provisions are still limited to concrete grades up to $50 \mathrm{MPa}$.

The first experimental program on double-skin CFDST with CHS-CHS section was developed by Tao et al. [5]. The concrete compressive strength was $40 \mathrm{MPa}$ and, for each specimen, the concentric steel tubes had the same thickness. Under axial loads, the plastic fold mechanism controlled the failure of the outer tube whereas the inner tube failed by local buckling for high values of $D / t$. The authors stated that the increment in the compressive strength of the concrete had to be considered to accurately predict the ultimate failure load. In the same line, Uenaka et al. [7] performed a series of tests on CHS-CHS sections where the steel tubes had the same thickness. This work focused on the study of the confinement and in this case the concrete had a compressive strength of $19 \mathrm{MPa}$.

Following the new trend of taking profit of the inner steel tube by filling it with concrete in order to obtain the so called double-tube sections, Liew and Xiong [8] executed a series of tests on CHS-CHS stub columns filled with UHSC (up to $200 \mathrm{MPa}$ ). Predictions 
provided by EC4-1-1 [6] were compared with the experimental results, showing a good agreement and a safe trend.

In contrast to the numerous publications on tests carried out on CFDST stub columns, the number of experimental programs on slender columns is still scarce. In this field, it is worth to mention the work developed by Essopjee and Dundu [9] on double-skin circular tube columns (inner steel tube empty) with a thickness combination thick-thin. In total, 32 columns were tested and the nominal compressive strength of the outer ring was $30 \mathrm{MPa}$. An extensive comparison with predictions given by the European code EC4-1-1 [6] was included in the publication together with a new proposal for the buckling curve. For slender double-skin CFDST columns, overall buckling was the type of failure detected.

In parallel, alternative configurations for multi-story buildings are appearing consisting of a massive steel section embedded inside the concrete core of the CFST column with the objective of maintaining a high axial capacity (Neuenschwander et al. [10], Schaumann and Kleibömer [11]).

Thus, the review of the existing literature highlights the lack of campaigns dealing with the characterization of slender CFDST columns and the study of the application of UHSC. Besides, most of the CFDST columns tested had a thick-thin cross-sectional configuration (the outer steel tube is thicker than the inner one) and no published results were found for the opposite combination.

Therefore, this paper presents the results of an experimental program where both double-skin and double-tube slender concrete-filled steel tubular columns were tested and compared. The main objective of this work is to evaluate the structural behaviour of such innovative cross-sections subjected to axial compression. For comparison purposes, different cross-sectional configurations varying the location of the UHSC and the thick steel tube were considered and the corresponding CFST columns of reference were also tested. These tests 
are included in the framework of an extended experimental program which will be subsequently completed with the corresponding tests under eccentric loads and also under fire.

\section{EXPERIMENTAL TESTS}

\subsection{General}

In the last years, the authors have developed several experimental campaigns to test the buckling resistance at room temperature of slender CFST columns. Tests on CFST columns of circular, square, rectangular and elliptical cross-sections have been carried out ([12]-[18][17]) but the experimental program presented in this work is the first on circular slender CFDST sections performed.

Through this campaign, the effect of three parameters was analysed. On the one hand, the influence of the concrete strength was studied by combining normal strength concrete and ultra-high strength concrete at different parts of the cross-section. The other two parameters were the location of the concrete with higher compressive strength (inner core or outer ring) and the ratio between the steel tubes thicknesses.

Therefore, with this aim, 14 composite columns were tested. For comparison purposes, the cross-section of a CFST column previously tested under fire was taken as a basis (tests C3 from [17]) for the design of the current program. Thus, the CFDST columns cross-sections were selected so as to assure that the total area of steel was the same in all the specimens ( $\pm 4 \%$ ). The geometric characteristics of the different cross-sections and other details can be consulted in Fig. 2 and Fig. 3. Two different series of 6 specimens each can be distinguished according to the type of concrete infill of the outer ring: Series 1 with normal strength concrete of grade C30 (Fig. 2a) and Series 2 with ultra-high strength concrete of grade C150 (Fig. 2b). For each series, the compressive strength of the concrete filling the inner core of the 
double-tube specimens varied between C30 and C150. In 4 of the specimens the inner core remained unfilled (i.e. double-skin). In Table 1 the real compressive strengths obtained through the material tests are summarised together with the geometric data of the columns.

In this experimental campaign, also two CFST columns (Fig. 2c) with the same outer steel tube and filled with normal strength concrete and ultra-high strength concrete respectively were tested as references to compare and analyse the results. Their properties are described in Table 1.

As exposed before, the influence of the ratio between the steel tubes thicknesses was also assessed. In the fire situation, previous results [17] pointed out the convenience of setting the thick tube in the inner part of the section (thin-thick). However, at room temperature, the opposite combination (thick-thin) is more efficient, according to previous published work [17]. The importance of studying this parameter resides in confirming this fact since in the design process an overall compromise is desirable. With this aim, 6 of the specimens had a thin outer tube and a thick inner tube (thin-thick) and, oppositely, the rest of columns consist of a thick outer tube and a thin inner tube (thick-thin). In Fig. 2, the difference between these two configurations can be clearly observed and in Table 1 all the details are included.

\subsection{Column specimens and test setup}

Although the tests were performed at the laboratories of the Universitat Jaume I in Castellón (Spain), all the columns were prepared at the Universitat Politècnica de València (Spain). At both ends of each column a steel plate with dimensions 300x300x15 mm was welded to help to carry out the test under pinned-pinned (P-P) end conditions. The same horizontal testing frame with capacity of $5000 \mathrm{kN}$ employed in the experimental campaigns described in [12]-[17] was used in this program where the buckling length of the columns was $3315 \mathrm{~mm}$. In Fig. 4, the test set-up is represented with detail. A small eccentricity of $5 \mathrm{~mm}$ 
was considered when the load was applied with the aim of controlling the plane of failure of the columns. In order to measure the deflection at different points along the column, linear variable displacement transducers (LVDTs) were placed at five points along the column $(0.25 \mathrm{~L}, 0.375 \mathrm{~L}, 0.5 \mathrm{~L}, 0.625 \mathrm{~L}$ and $0.75 \mathrm{~L})$. For each test, the pertinent displacement control test was performed once the specimen was positioned to assure the proper measurement of the post-peak behaviour.

\subsection{Material properties}

Steel tubes

As can be observed in Fig. 2, in this experimental program all the CFDST columns had CHS-CHS section with both the inner tube and the outer tube consisting of circular steel hollow sections. Due to the available stock of the supplier, the nominal yield strength of the steel tubes varied between S355 for those tubes with a thickness of 6 and $8 \mathrm{~mm}$ and S275 for those tubes which are 3mm thick. The corresponding tests were performed for each column (3 coupon tests per tube) to determine the real yield strength of the hollow steel tubes $\left(f_{y}\right)$. These data can be consulted in Table 1. According to the European standards, the modulus of elasticity of steel was set to $210 \mathrm{GPa}$.

\section{Concrete}

In the case of the concrete infill, two types of nominal compressive strength were contemplated in this campaign: $30 \mathrm{MPa}$ and $150 \mathrm{MPa}$. In order to obtain the actual compressive strength of concrete $\left(f_{c}\right)$, the pertinent standard tests were carried out on both the 150x300 mm cylinder and the $100 \mathrm{~mm}$ cube. From the values of the strength of the cubic samples, the equivalent cylinder compressive strength was obtained according to Eurocode 2 [19]. The sets of concrete samples were prepared in a planetary mixer and cured in standard 
conditions during 28 days. The day when the experiment of a certain specimen was going to be performed, the corresponding samples were tested, as shown in Table 1.

\section{RESULTS}

\subsection{Experimental results}

For each specimen, the evolution of the axial force and the lateral displacement at midspan were registered during the tests and the different curves are presented in Fig. 5 and Fig. 6 for Series 1 and Series 2 respectively. The response of the corresponding CFST columns of reference is also plotted. The value of the maximum axial load achieved for each column $\left(N_{u}\right)$ is summarized in Table 1, where also the results of the reference tests are included (i.e. CFST1 for Series 1 and CFST2 for Series 2).

\section{Series 1: NSC in the outer ring}

As can be observed in Fig. 5, the specimens with NSC in the outer ring and thick-thin steel tubes configuration (NR1, NR2 and NR3) showed less maximum load values than the CFST of reference (CFST1, Table 1), being obviously the double-skin column that with the minimum capacity (NR1). This response can be due to the lack of effectiveness of these specimens in facing the second order effects given the reduction in the moment of inertia of the total cross-section. If the inner tube is filled with concrete, even if it is UHSC, the maximum load is less than that observed for the CFST1.

On the contrary, if the thick steel tube is the inner one and, in turn, it is filled with concrete (NR5 and NR6), the maximum load measured is higher than that achieved by the CFST1 for both types of concrete, although the increment due to the UHSC is less than that expected compared to the improvement due to the NSC. For the double-skin column of this configuration (NR4), the load capacity does not augment compared to the column of reference and is very similar to the response of the column NR2. 
Therefore, the effect of the UHSC depends mainly on the cross-sectional steel tubes configuration and the effect of the concrete of the outer ring is less significant.

\section{Series 2: UHSC in the outer ring}

According to the results displayed in Fig. 6, filling the outer ring with UHSC has more pronounced effect than filling it with NSC and the load capacity generally improves. Only in the two double-skin columns of this series (NR7 and NR10) the maximum load is less than that of the corresponding CFST column (CFST2, Table 1).

For both types of steel tubes configurations (thin-thick and thick-thin), filling the inner tube with concrete increases considerably the load capacity, being this enhancement higher for UHSC. For Series 2, the response is practically independent of the steel thicknesses distribution having very similar response the pairs of specimens filled with NSC, NR8 and NR11, and those with UHSC, NR9 and NR12. As expected, the maximum load is registered for those columns filled completely with UHSC.

In view of the results, in Series 2 the cross-sectional stiffness is dominated by the outer ring contrarily to the trend observed for Series 1.

\subsection{Concrete-steel contribution ratio (CSCR)}

Since one of the objectives of this work is to determine the influence of the location of the type of concrete and the thick steel tube in the cross-sectional configuration, an analysis of the mechanical contribution of the different components obtained from the experimental results is carried out.

For the study of CFST columns, the use of these parameters is usual and taking as a basis the same concept, a new mechanical ratio can be defined: the concrete-steel contribution ratio (CSCR). 
In the process of analysing the results and drawing conclusions, it is necessary to take into account that all these specimens have the same length but not the same slenderness since it changes as cross-sectional properties do.

Considering that the expected improved mechanical behaviour of a CFDST column with respect to a CFST column is due to the extra inner steel tube, the CSCR is calculated as the ratio between the maximum load achieved by the CFDST $\left(N_{u}\right)$ and the maximum load measured for the corresponding CFST column ( $\left.N_{u, C F S T}\right)$. Thus, for the same area of steel in the cross-section, a value less than unity means that the new redistribution of the steel thicknesses together with the infill of the inner tube does not enhance the load-bearing capacity of the original CFST of reference.

$\operatorname{CSCR}=\frac{N_{u}}{N_{u, C F S T}}$

In Table 2 and in Fig. 7 are shown the values obtained for this parameter which help to quantify the trend observed previously through the load-deflection curves.

\section{Series 1: NSC in the outer ring}

Since the CSCR is less than unity in all the thin-thick specimens with NSC in the outer ring, it means that this configuration of double-tube columns does not improve the CFST column behaviour, not even when UHSC is placed in the inner tube.

However, for the thick-thin columns with NSC in the outer ring, the presence of concrete in the inner tube has a positive effect on their mechanical response, being this improvement higher for UHSC.

Again, it is observed how, in this series, the position of the thick tube affects the influence of the concrete placed at the inner tube.

\section{Series 2: UHSC in the outer ring}

With regard to Series 2, with UHSC in the outer ring, the values obtained for the CSCR are practically equal for the columns of both configurations of steel tubes: thin-thick and thin- 
thick. It confirms that, for these specimens, the component dominating the mechanical behaviour is the UHSC outer ring.

It is worth to mention that the CSCR of the double-skin columns (NR7 and NR10) is near to unity, which means that it is possible to obtain the same bearing capacity with a column with less self-weight.

\subsection{Inner concrete contribution ratio (ICCR)}

The inner concrete contribution ratio (ICCR) is employed to evaluate the variation in the load-bearing capacity of a double-skin CFDST column when its inner steel tube is filled with concrete (double-tube).

It is defined as the relation between the maximum load measured for the double-tube column and that registered during the experiment for the corresponding double-skin column so that a value more than unity indicates the convenience of filling the inner tube with concrete.

$I C C R=\frac{N_{u, C F D S T, \text { double }- \text { tube }}}{N_{u, C F D S T, \text { double-skin }}}$

In Table 2 this value is presented and in Fig. 8 the results are shown graphically.

\section{Series 1: NSC in the outer ring}

For Series 1, the values of the ICCR are generally higher than for Series 2, which implies that filling the inner steel tube with concrete is more efficient for CFDST columns with NSC in the outer ring.

With regard to the cross-sectional configuration of steel tubes thicknesses, an increment in the ICCR is observed for Series 1 between the thin-thick and the thick-thin columns as displayed in Fig. 8.

\section{Series 2: UHSC in the outer ring}


In contrast, the contribution of the concrete infill of the inner steel tube is less important for thick-thin columns if the outer ring is filled with UHSC. This corroborates once more the fact that, in this series, the behavior is dominated by the outer part of the section and that, besides, his phenomenon is enhanced if, in turn, the outer part also includes the thick steel tube.

\section{STUDY AND DISCUSSION OF EUROCODE 4}

In order to assess the simplified design method included in EN 1994-1-1[6] for composite members, the results given by the method proposed in its Clause 6.7.3 will be contrasted to the experimental measurements extracted from the tests executed in this program. According to Clause 6.7.3.5(2) from [6], the design axial buckling load at room temperature $\boldsymbol{N}_{\boldsymbol{b}, \boldsymbol{R} \boldsymbol{d}}$ for members in axial compression can be calculated by:

$$
N_{b, R d}=\chi \cdot N_{p l, R d}
$$

where $\boldsymbol{N}_{\boldsymbol{p l}, \boldsymbol{R} \boldsymbol{d}}$ is the plastic resistance of the composite section according to 6.7.3.2(1) and $\chi$ is the buckling reduction factor given in EN 1993-1-1 [20], function of the corresponding buckling curve and the relative slenderness of the column $\bar{\lambda}$ defined in Clause 6.7.3.3(2) as:

$\bar{\lambda}=\sqrt{\frac{N_{p l}}{N_{c r}}}=\sqrt{\frac{A_{c} f_{c}+A_{s} f_{y}}{\frac{\pi^{2} E I}{L^{2}}}}$

where $E I=E_{s} I_{s}+0.6 E_{c m} \cdot I_{c}$, and $I_{s}$ and $I_{c}$ are the second moment of inertia of the steel tube and the concrete core respectively; $E_{s}$ is the modulus of elasticity of steel; and $E_{c m}$ is the secant modulus of elasticity of concrete.

Since EC4 does not contemplate yet the possibility of employing this type of configuration with double tube, the inner steel is considered as an inner steel reinforcement 
for calculation purposes. For each specimen, the buckling curve ("a” or "b”) is properly selected from Table 5.5 in EN 1994-1-1 [6] according to its geometrical steel ratio.

Besides, it is worth to note that, for the aim of comparing, all the tested specimens are considered in this analysis although Eurocode 4 Part 1-1 [6] provisions are still limited to concrete grades up to $50 \mathrm{MPa}$.

The results obtained through this method are summarized in Table 1 (EC4 $e=0, N_{b, R d}$ ) and Fig. 9. As it can be seen, no defined trend is detected in terms of the steel tube thicknesses configuration or the UHSC location. In general, EC4 provides unsafe results on average for all the columns with an error around 15\%.

In view of the results, a second analysis was carried out considering the actual small eccentricity of $5 \mathrm{~mm}$ employed to apply the axial load during the experiments. Under this assumption, the bearing capacity of the column is defined by the design buckling resistance moment according to Clause 6.7.3.6 of Eurocode 4 Part 1-1 [6]:

$$
M_{b, R d}=\alpha_{M} \cdot M_{p l, N_{E d}}
$$

where $\alpha_{M}$ is a non-dimensional coefficient ( $\alpha_{M}=0.9$ for S355 steel) and $M_{p l, N e d}$ is the plastic bending resistance of the section obtained through the interaction curve $\mathrm{M}-\mathrm{N}$ taking into account the normal force applied and the initial eccentricity. Through an iterative process, the results obtained through this process are shown in Table 1 (EC4 $e=5, N_{b, R d}$ ) and Fig. 9.

In this situation, predictions given by Eurocode 4 result to be conservative oppositely to the values obtained previously, although again it is not observed any trend in the results in relation with the parameters studied.

Considering all the exposed above, it can be stated that the method in EC4 for members in axial compression provides unsafe results for evaluating the buckling resistance of concrete-filled dual steel tubular columns. However, when a small eccentricity is taken into account in the calculation process the trend changes considerably and the values obtained for 
the buckling resistance of these columns become conservative. It is worth to note the excessive influence in the load-bearing capacity of this minimal eccentricity of $5 \mathrm{~mm}$. In practice, this could become an issue for practitioners since this small value of eccentricities could be considered inherent to the processes of manufacturing and construction and not be explicitly taken into account design. Therefore, further studies, both numerical and experimental, would be needed for evaluating the actual accuracy of EC4 method including, besides, the employment of ultra-high strength concrete.

\section{SUMMARY AND CONCLUSIONS}

In this paper, the results of an experimental program on slender dual steel tubular columns filled with normal and ultra-high strength concrete were presented. This work provided novel results to this research field since the number of similar experimental campaigns available in the literature is scarce. The influence on the load-bearing capacity of different parameters was studied. The parameters were the concrete strength (normal strength and ultra-high strength concrete), the location of the concrete with higher compressive strength (inner core or outer ring) and the ratio between the inner and outer steel tube thicknesses. For this purpose, 14 specimens were tested: 12 CFDST columns divided into two series (Series 1: NSC outer ring and Series 2: UHSC outer ring) together with the two corresponding CFST columns which served as a reference.

The load-deflection curves were extracted and the maximum load achieved during the experiment was registered. From the test results it was found that the trends observed for both series were different, confirming the influence of the type of concrete placed in the outer ring.

Two coefficients were also employed in the analysis, the concrete-steel contribution ratio (CSCR) and the inner concrete contribution ratio (ICCR). After the study of this ratio, it was observed that for those columns with NSC outer ring, a double-tube column with the thick tube in the inner position can reach almost the same buckling load than a double-skin 
CFST column with the thick steel tube in the outer position and without inner concrete. Besides, it results also noteworthy the reduced effect presented by the UHSC in the inner core in comparison with NSC.

With respect to the columns with UHSC in the outer ring, the main conclusion drawn was that the maximum load is independent on the steel tubes thicknesses distribution. In these cases, the behavior is dominated by the UHSC outer ring. In addition, it was observed that the CSCR of the double-skin columns of this series is close to 1 , which proves that it is possible to obtain the same load-bearing capacity than a CFST column but with less weight.

Another aspect detected through the analysis of the ICCR values was the efficiency of filling the inner tube in those specimens with NSC outer ring with respect to those with UHSC outer ring, where this action has minor effect.

Finally, the design rules in Eurocode 4 were assessed by means of the tests results. Considering the limited cases of this work, it can be initially inferred that the method in EC4 Part 1.1 for members in axial compression provides unsafe results for evaluating the buckling resistance of CFDST columns. Nevertheless, adopting an initial small eccentricity $(e=5 \mathrm{~mm})$ produces considerably different results, being conservative in this case. Further tests are needed for evaluating the accuracy of EC4 method in a more reliable manner.

\section{ACKNOWLEDGMENTS}

The authors would like to express their sincere gratitude to the Spanish Ministry of Economy and Competitivity through the project BIA2012-33144 and to the European Community for the FEDER funds. 


\section{REFERENCES}

[1] Zhao, XL, Grzebieta, R. Strength and ductility of concrete filled double skin (SHS inner and SHS outer) tubes. Thin-Walled Structures 2002; 40, 199-213.

[2] Zhao X, Han L. Double skin composite construction. Progress in structural engineering and materials 2006; 8 (3):93-102

[3] Han, LH, Tao, Z, Huang, H, Zhao, XL. Concrete-filled double skin (SHS outer and CHS inner) steel tubular beam-columns. Thin-Walled Structures 2004; 42, 1329-1355.

[4] Elchalakani M, Zhao XL, Grzebieta R. Tests on concrete filled double-skin (CHS outer and SHS inner) composite short columns under axial compression. Thin-walled structures 2002; 40 (5):415-441.

[5] Tao, Z, Han, LH, Zhao, XL. Behaviour of concrete-filled double skin (CHS inner and CHS outer) steel tubular stub columns and beam-columns. Journal of Constructional Steel Research 2004; 60, 1129-1158.

[6] CEN. EN 1994-1-1, Eurocode 4: Design of composite steel and concrete structures. Part 1-1: General rules and rules for buildings. Brussels, Belgium: Comité Européen de Normalisation; 2004

[7] Uenaka, K., Kitoh, H. y Sonoda, K. 2010. Concrete filled double skin circular stub columns under compression. Thin-Walled Structures, 48, 19-24.

[8] Liew JYR, Xiong DX. Experimental investigation on tubular columns infilled with ultrahigh strength concrete. Tubular Structures XIII. Boca Raton: Crc Press-Taylor \& Francis Group. 2011; 637-645.

[9] Essopjee, Y, Dundu, M. Performance of concrete-filled double-skin circular tubes in compression. Composite Structures 2015; 133, 1276-1283. 
[10] Neuenschwander M., Knobloch M., Fontana M. Fire behaviour of concrete filled circular hollow section columns with massive steel core, Proceedings of the International Colloquium Stability and Ductility of Steel Structures SDSS, September 8-10, 2010, Rio de Janeiro, Brazil.

[11] Schaumann P., Kleibömer I., Experimentelle Untersuchungen zum Trag- und Erwärmungsverhalten von Verbundstützen mit massivem Einstellprofil im Brandfall" / "Experimental investigations on the structural and thermal behaviour of composite columns with embedded massive steel core” ( In German), 19. DASt-Kolloqium, October 2014, Hannover, Germany (In press).

[12] Portoles J M, Romero M L, Bonet J L, Filippou F C. Experimental study of high strength concrete-filled circular tubular columns under eccentric loading. Journal of constructional steel research 2011; 67(4):623-633.

[13] Portoles JM, Serra E, Romero ML. Influence of ultra-high strength infill in slender concrete-filled steel tubular columns. Journal of constructional steel research 2013; 86:107-114.

[14] Hernández-Figueirido D, Romero ML, Bonet JL, Montalvá JM. Ultimate capacity of rectangular concrete-filled steel tubular columns under unequal load eccentricities, Journal of Constructional Steel Research 2012; 68:107-117.

[15] Hernández-Figueirido D, Romero ML, Bonet, JL, Montalvá JM. Influence of Slenderness on High-Strength Rectangular Concrete-Filled Tubular Columns with Axial Load and Nonconstant Bending Moment, J. Struct. Eng. 2012; 138(12): 1436-1445.

[16] Espinos A, Romero ML, Portolés JM, Hospitaler A. Ambient and fire behavior of eccentrically loaded elliptical slender concrete-filled tubular columns. Journal of constructional steel research 2014; 100: 97-107. 
[17] Romero ML, Espinos A, Portolés JM, Hospitaler A, Ibañez C. Slender double-tube ultrahigh strength concrete-filled tubular columns under ambient temperature and fire. Engineering Structures 2015; 99: 536-545.

[18] Espinós A, Romero M, Serra E, Hospitaler A. Circular and square slender concrete-filled tubular columns under large eccentricities and fire. Journal of Constructional Steel Research 2015; 110: 90-100.

[19] CEN EN 1992-1-1, Eurocode 2: Design of concrete structures. Part 1.1: General rules and rules for buildings. Brussels, Belgium: Comité Européen de Normalisation; 2004.

[20] CEN. EN 1993-1-1, Eurocode 3: Design of steel structures. Part 1.1: General rules and rules for buildings. Brussels, Belgium: Comité Européen de Normalisation; 2005. 
Romero ML, Ibañez C, Espinos A, Portolés JM, Hospitaler A. Influence of ultra-high strength concrete on circular concretefilled dual steel columns. 2017. Structures; 3: 13-20.

doi: 10.1016/j.istruc.2016.07.001

a)

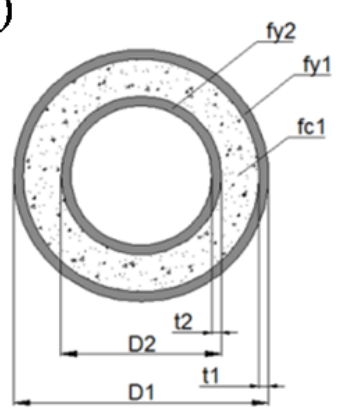

b)

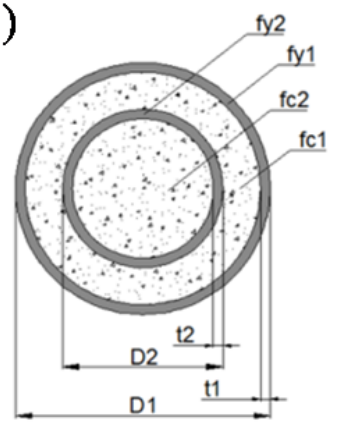

Fig. 1. CFDST sections: a) Double-skin b) Double-tube 
Romero ML, Ibañez C, Espinos A, Portolés JM, Hospitaler A. Influence of ultra-high strength concrete on circular concretefilled dual steel columns. 2017. Structures; 3: 13-20.

doi: 10.1016/j.istruc.2016.07.001

a)

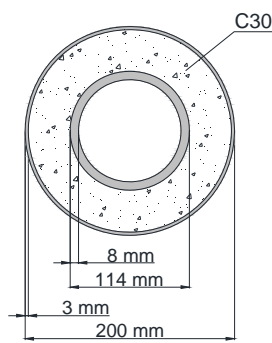

C200-3-30_C114-8-00

NR1

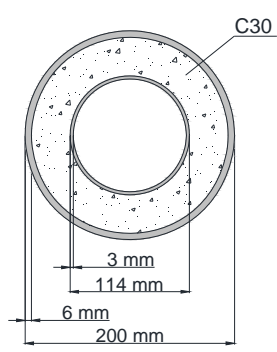

C200-6-30_C114-3-00

NR4

b)

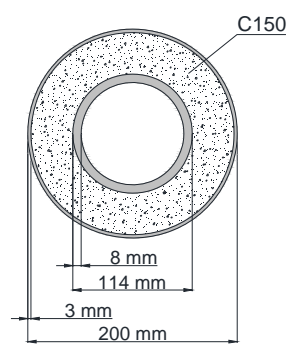

C200-3-150 C114-8-00

NR7

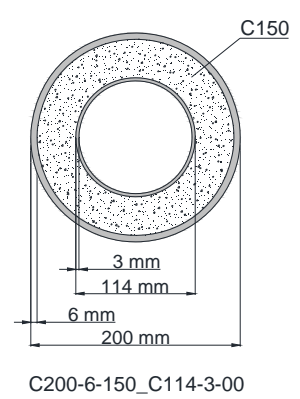

NR10

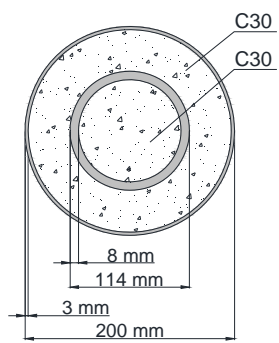

C200-3-30_C114-8-30

NR2

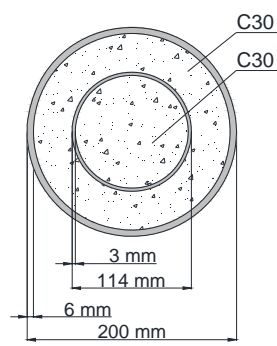

C200-6-30_C114-3-30

NR5

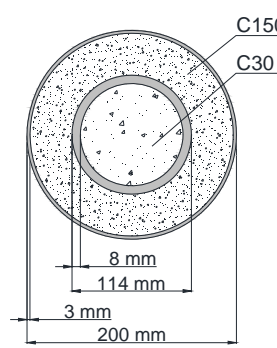

C200-3-150_C114-8-30

NR8

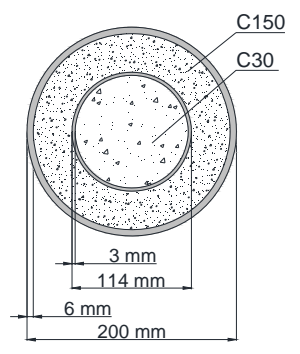

C200-6-150_C114-3-30

NR11

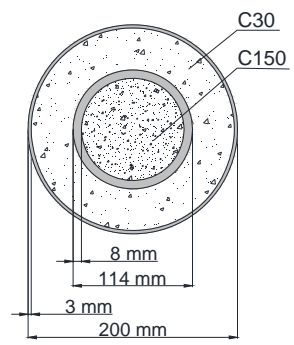

C200-3-30_C114-8-150

NR3

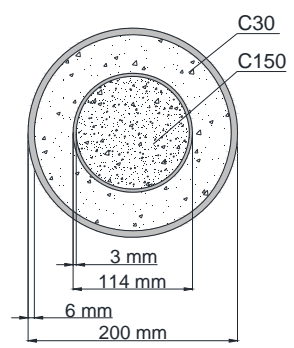

C200-6-30_C114-3-150 NR6

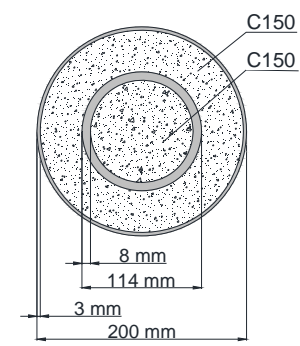

C200-3-150_C114-8-150

NR9

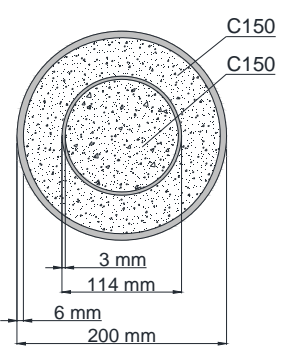

C200-6-150_C114-3-150

NR12

c)

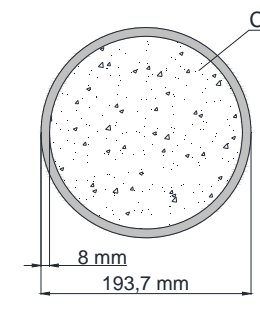

C193.7-8-30
C150

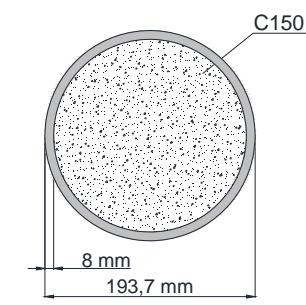

C193.7-8-150

CFST1

CFST2

Fig. 2. Room temperature tests: a) Series 1 . Outer ring C30 b) Series 2. Outer ring C150 c) CFST specimens 
Romero ML, Ibañez C, Espinos A, Portolés JM, Hospitaler A. Influence of ultra-high strength concrete on circular concretefilled dual steel columns. 2017. Structures; 3: 13-20.

a)

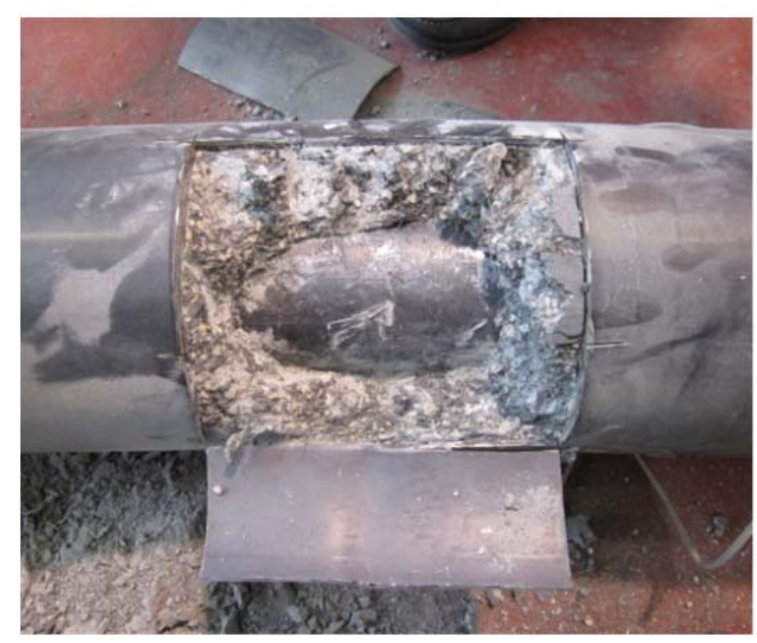

b)

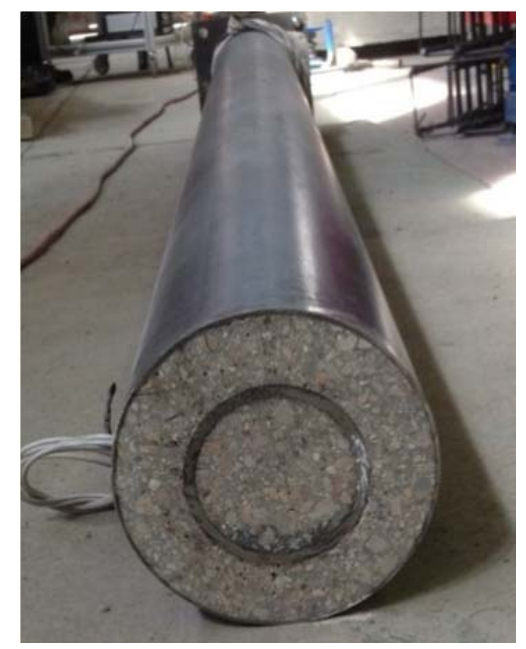

Fig. 3. Room temperature tests: a) Column after test b) Cross-section detail 
Romero ML, Ibañez C, Espinos A, Portolés JM, Hospitaler A. Influence of ultra-high strength concrete on circular concretefilled dual steel columns. 2017. Structures; 3: 13-20.

doi: 10.1016/j.istruc.2016.07.001

Hydraulic jack

Load cell

Column

Testing frame

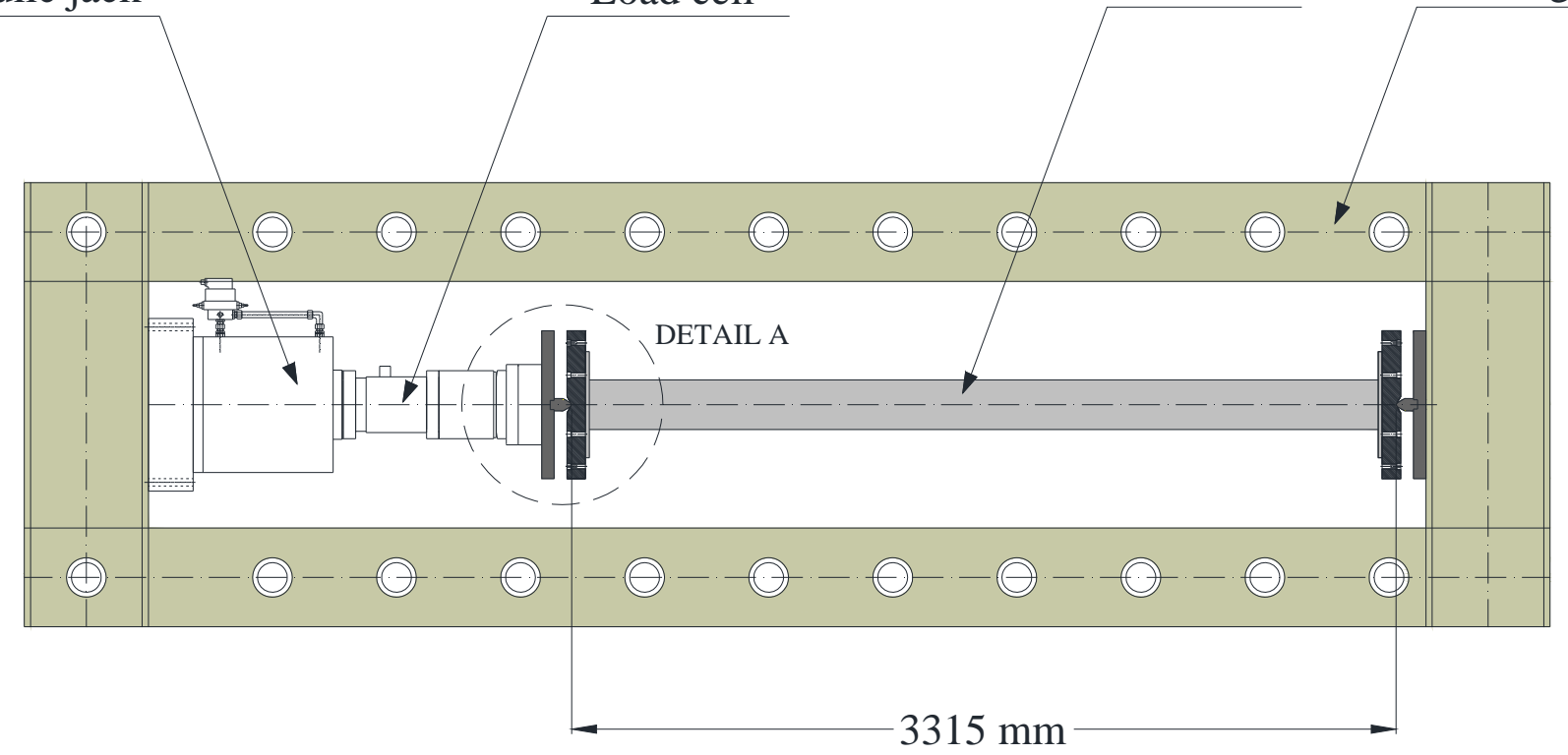

b)

Knife bearing
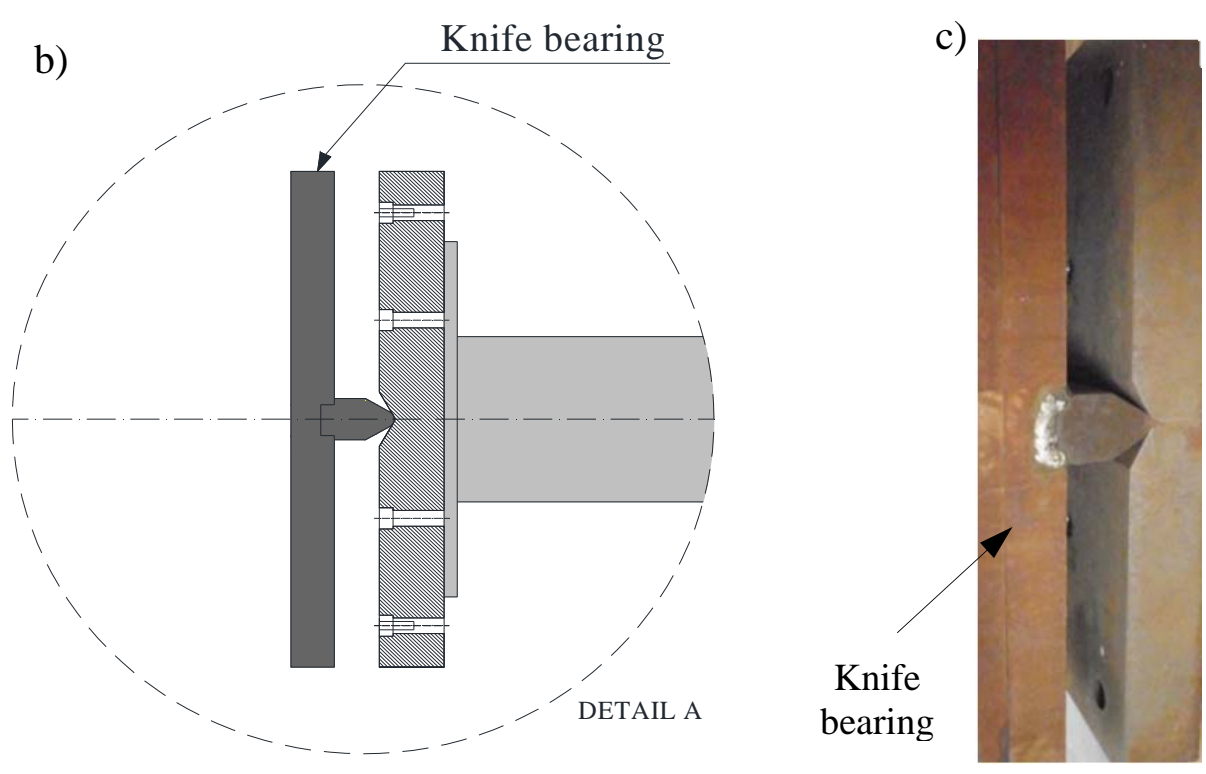

d)

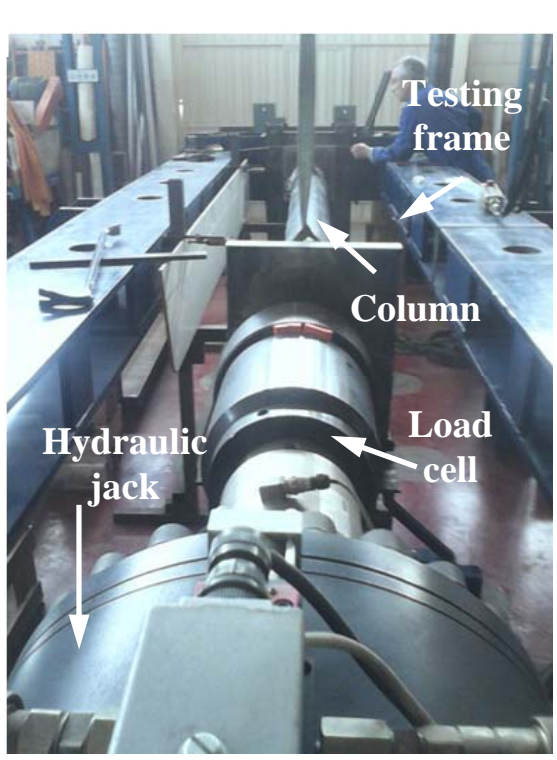

Fig. 4. Test set-up: a) Schematic view b) Detail of the support c) Knife bearing d)Test set-up at laboratory 


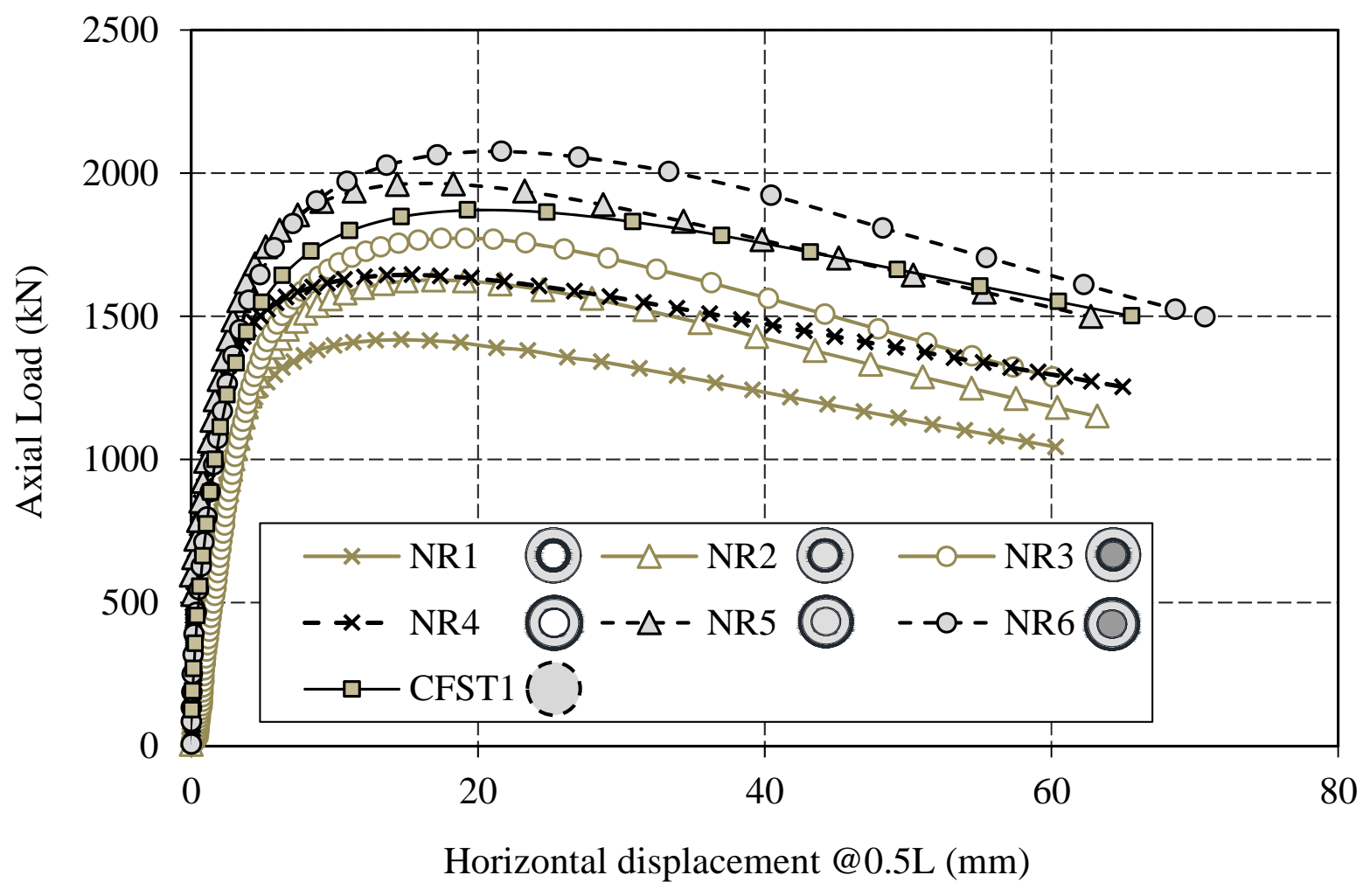

Fig. 5. Axial load versus mid-span displacement in Series 1 (NSC outer ring). 


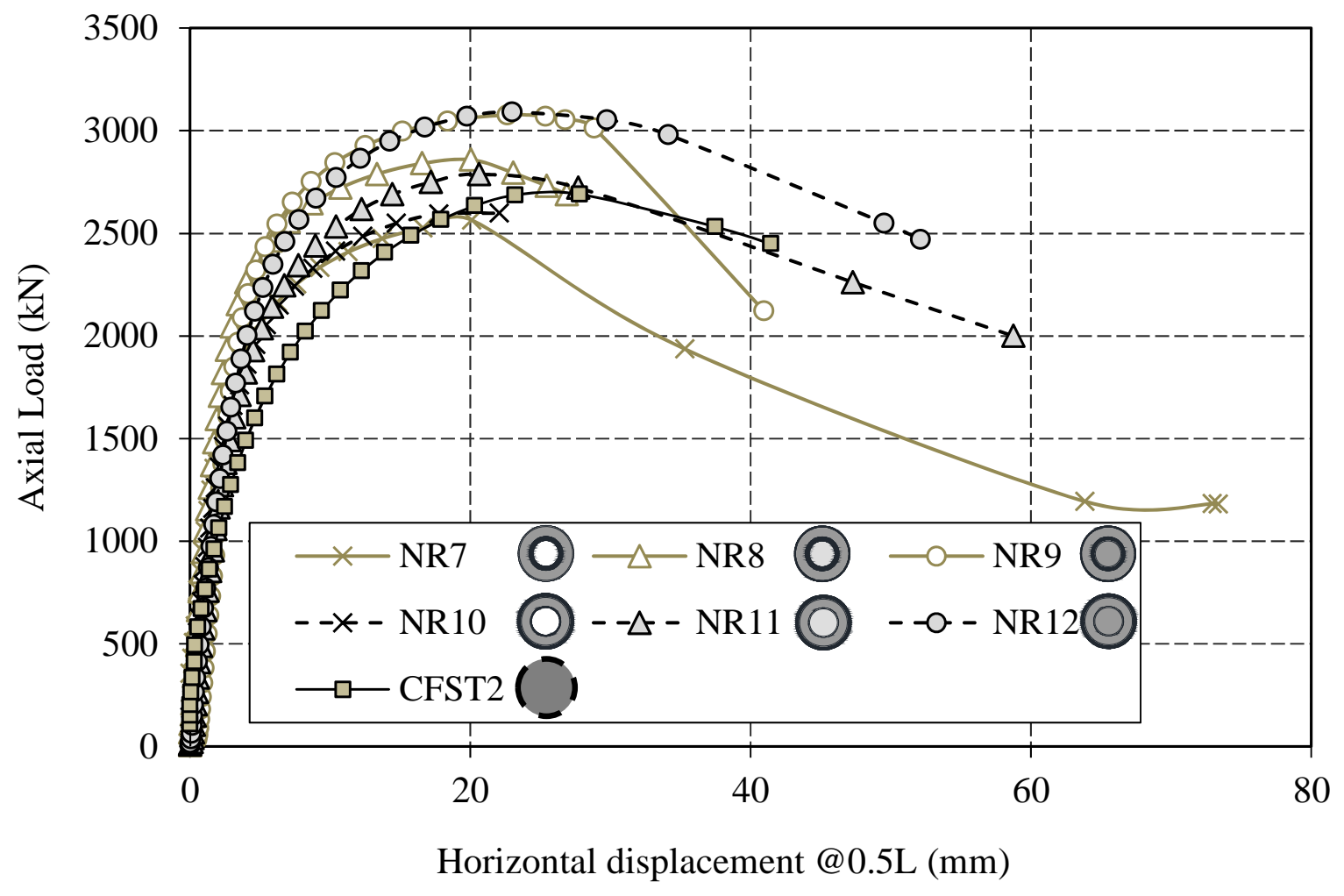

Fig. 6. Axial load versus mid-span displacement in Series 2 (UHSC outer ring). 
Romero ML, Ibañez C, Espinos A, Portolés JM, Hospitaler A. Influence of ultra-high strength concrete on circular concretefilled dual steel columns. 2017. Structures; 3: 13-20.

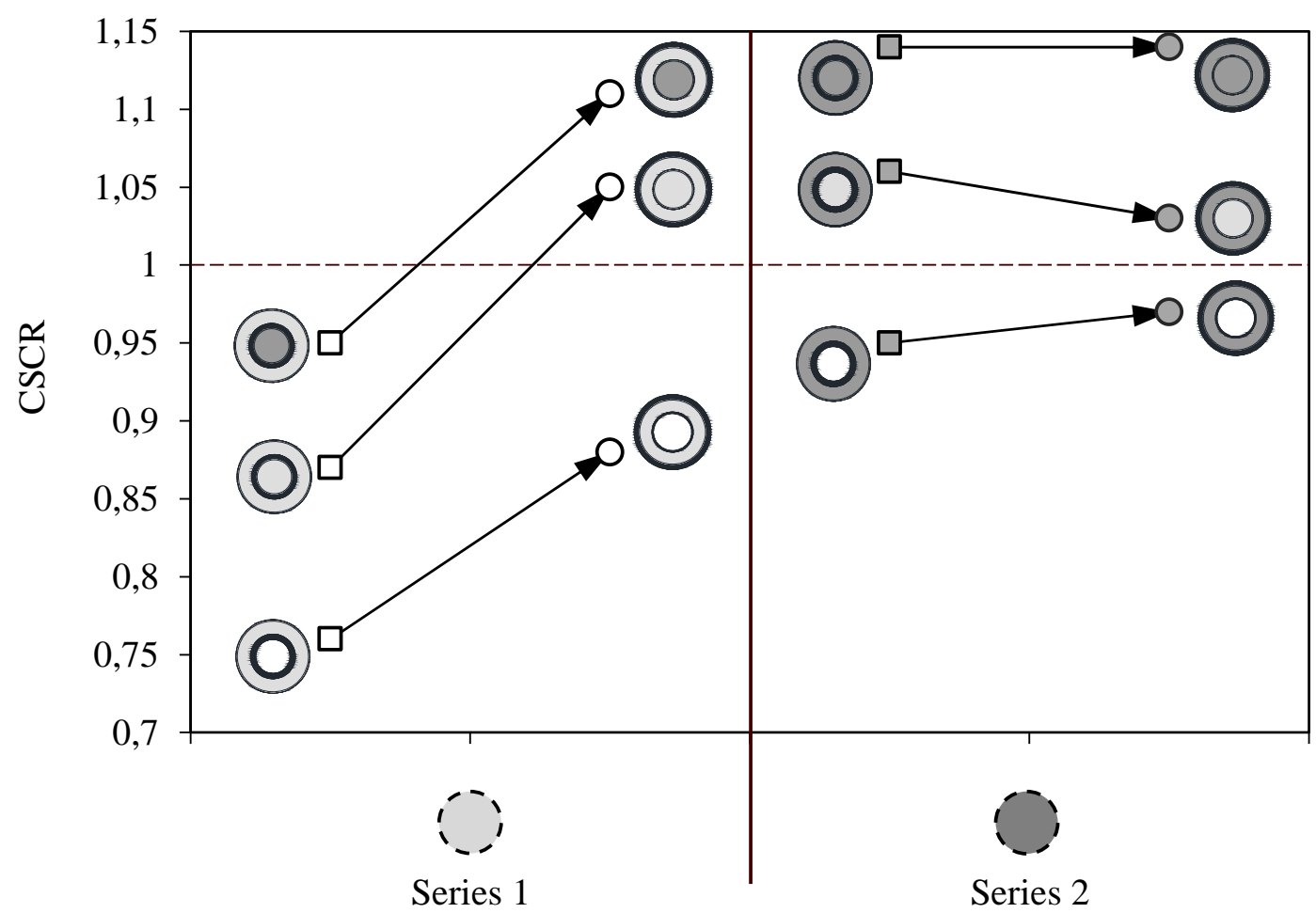

Fig. 7. Concrete-Steel contribution ratio 
Romero ML, Ibañez C, Espinos A, Portolés JM, Hospitaler A. Influence of ultra-high strength concrete on circular concretefilled dual steel columns. 2017. Structures; 3: 13-20.

doi: 10.1016/j.istruc.2016.07.001

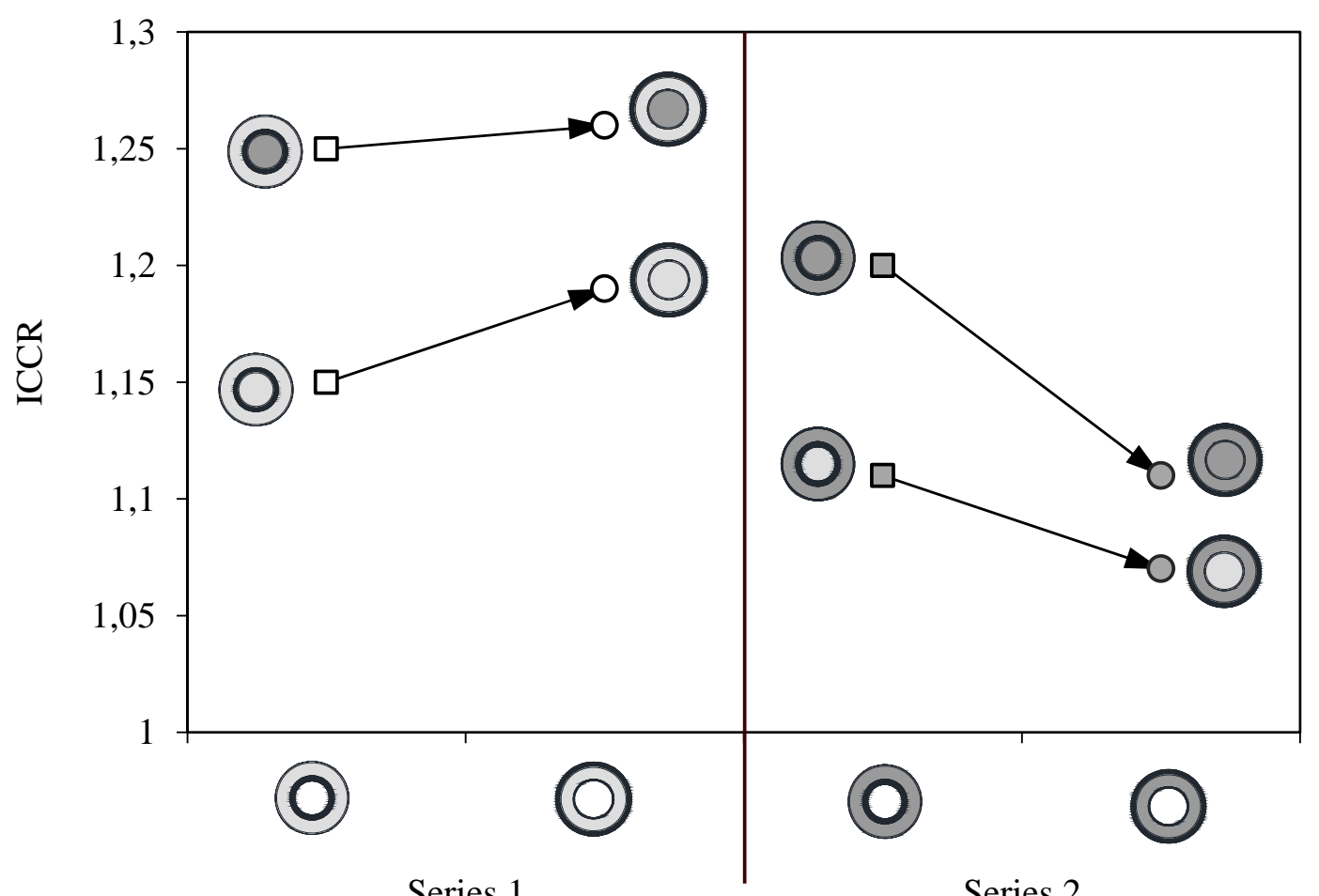

Series 1

Series 2

Fig. 8. Inner concrete contribution ratio 
Romero ML, Ibañez C, Espinos A, Portolés JM, Hospitaler A. Influence of ultra-high strength concrete on circular concretefilled dual steel columns. 2017. Structures; 3: 13-20.

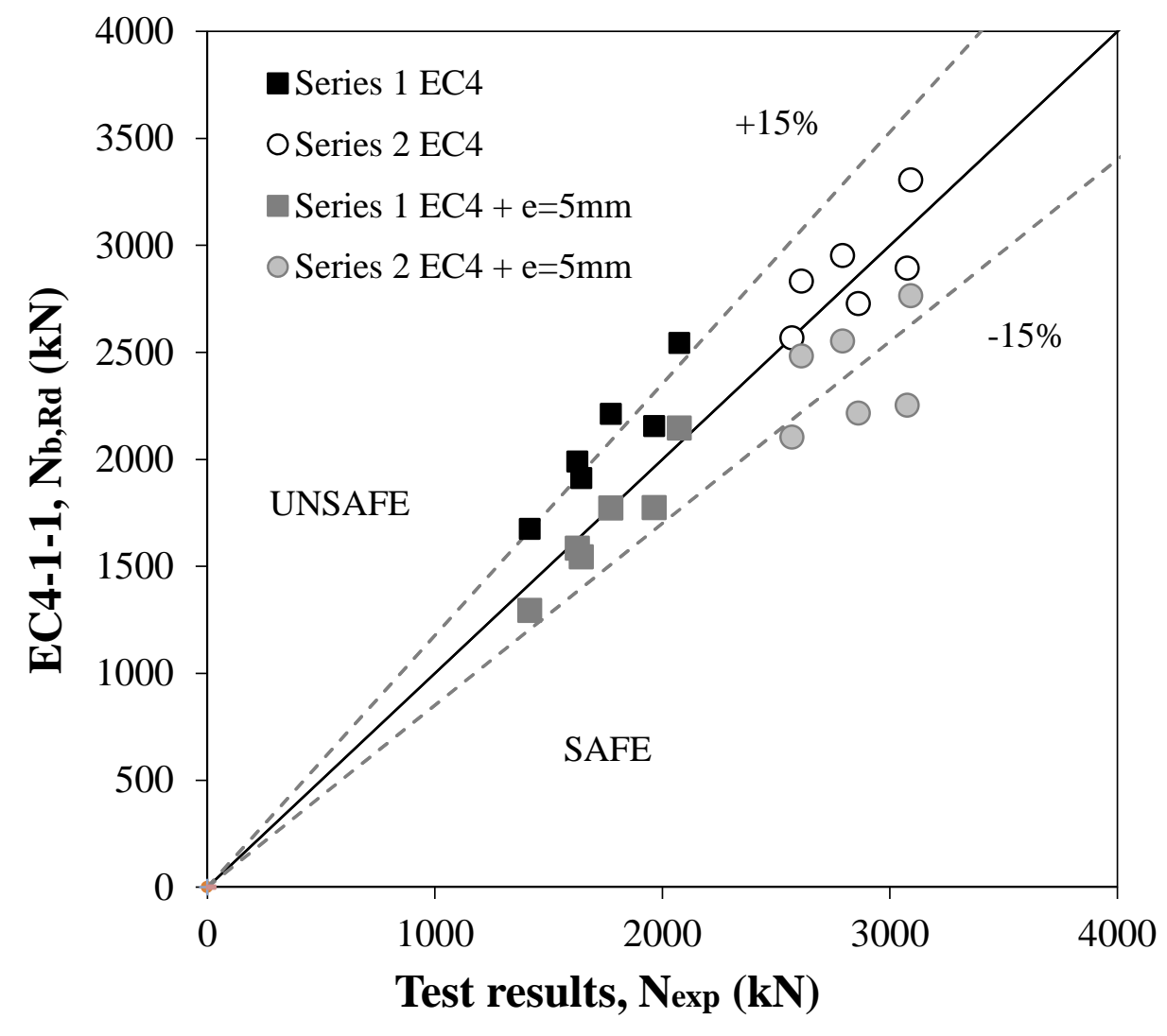

Fig. 9. Comparison between calculated buckling load (EC4) and test load 
Table 1. Details of the column specimens and test results

\begin{tabular}{|c|c|c|c|c|c|c|c|c|c|c|c|c|}
\hline \multirow{2}{*}{ ID } & \multirow[b]{2}{*}{ Column specimen } & \multicolumn{4}{|c|}{ Outer Tube } & \multicolumn{4}{|c|}{ Inner Tube } & \multirow{2}{*}{$\begin{array}{c}\operatorname{Exp} \\
\begin{array}{c}N_{u} \\
(\mathrm{kN})\end{array}\end{array}$} & \multirow{2}{*}{$\begin{array}{c}\begin{array}{c}\text { EC4 } \\
e=0\end{array} \\
\begin{array}{c}N_{b, R d} \\
(\mathrm{kN})\end{array}\end{array}$} & \multirow{2}{*}{$\begin{array}{c}\mathrm{EC4} \\
e=5\end{array}$} \\
\hline & & $\begin{array}{c}D_{\text {ext }} \\
(\mathrm{mm})\end{array}$ & $\begin{array}{c}t_{\text {ext }} \\
(\mathrm{mm})\end{array}$ & $\begin{array}{c}f_{y, e x t} \\
\text { (MPa) }\end{array}$ & $\begin{array}{l}f_{c, \text { ext }} \\
(\mathrm{MPa})\end{array}$ & $\begin{array}{c}D_{\text {int }} \\
(\mathrm{mm})\end{array}$ & $\begin{array}{c}t_{i n t} \\
(\mathrm{~mm})\end{array}$ & $\begin{array}{c}f_{y, \text { int }} \\
\text { (MPa) }\end{array}$ & $\begin{array}{c}f_{c, \text { int }} \\
(\mathrm{MPa})\end{array}$ & & & \\
\hline \multicolumn{13}{|l|}{ Series 1} \\
\hline NR1 & C200-3-30-C114-8-00 & 200 & 3 & 300 & 36 & 114.3 & 8 & 377 & 0 & 1418 & 1674 & 1294 \\
\hline NR2 & C200-3-30-C114-8-30 & 200 & 3 & 332 & 45 & 114.3 & 8 & 403 & 42 & 1627 & 1990 & 1584 \\
\hline NR3 & C200-3-30-C114-8-150 & 200 & 3 & 272 & 43 & 114.3 & 8 & 414 & 134 & 1774 & 2213 & 1772 \\
\hline NR4 & C200-6-30-C114-3-00 & 200 & 6 & 407 & 35 & 114.3 & 3 & 343 & 0 & 1644 & 1912 & 1545 \\
\hline NR5 & C200-6-30-C114-3-30 & 200 & 6 & 377 & 44 & 114.3 & 3 & 329 & 40 & 1964 & 2156 & 1775 \\
\hline NR6 & C200-6-30-C114-3-150 & 200 & 6 & 386 & 43 & 114.3 & 3 & 343 & 123 & 2076 & 2543 & 2145 \\
\hline \multicolumn{13}{|l|}{ Series 2} \\
\hline NR7 & C200-3-150-C114-8-00 & 200 & 3 & 300 & 138 & 114.3 & 8 & 377 & 0 & 2571 & 2567 & 2103 \\
\hline NR8 & C200-3-150-C114-8-30 & 200 & 3 & 332 & 139 & 114.3 & 8 & 403 & 43 & 2862 & 2728 & 2216 \\
\hline NR9 & C200-3-150-C114-8-150 & 200 & 3 & 272 & 142 & 114.3 & 8 & 414 & 140 & 3077 & 2893 & 2252 \\
\hline NR10 & C200-6-150-C114-3-00 & 200 & 6 & 407 & 137 & 114.3 & 3 & 343 & 0 & 2612 & 2833 & 2483 \\
\hline NR11 & C200-6-150-C114-3-30 & 200 & 6 & 377 & 137 & 114.3 & 3 & 329 & 45 & 2793 & 2952 & 2552 \\
\hline NR12 & C200-6-150-C114-3-150 & 200 & 6 & 386 & 146 & 114.3 & 3 & 343 & 140 & 3093 & 3305 & 2765 \\
\hline \multicolumn{13}{|c|}{ CFST specimens } \\
\hline CFST1 & C193.7-8-30 & 193.7 & 8 & 444 & 40 & & & & & 1871 & 2479 & \\
\hline CFST2 & C193.7-8-150 & 193.7 & 8 & 444 & 142 & & & & & 2703 & 3700 & \\
\hline
\end{tabular}

t=thickness

$D=$ diameter $\quad \mathrm{BC}=$ pinned-pinned 
Romero ML, Ibañez C, Espinos A, Portolés JM, Hospitaler A. Influence of ultra-high strength concrete on circular concretefilled dual steel columns. 2017. Structures; 3: 13-20.

Table 2. Concrete-steel contribution ratio and inner concrete contribution ratio

\begin{tabular}{|c|c|c|c|c|c|}
\hline ID & Column specimen & CFST column & CSCR & Double-skin column & ICCR \\
\hline \multicolumn{6}{|l|}{ Series 1} \\
\hline NR1 & C200-3-30-C114-8-00 & \multirow{6}{*}{ C193.7-8-30-00 } & 0.76 & \multirow{3}{*}{$\begin{array}{c}\text { NR1 } \\
\text { C200-3-30-C114-8-00 }\end{array}$} & --- \\
\hline NR2 & C200-3-30-C114-8-30 & & 0.87 & & 1.15 \\
\hline NR3 & C200-3-30-C114-8-150 & & 0.95 & & 1.25 \\
\hline NR4 & C200-6-30-C114-3-00 & & 0.88 & \multirow{3}{*}{$\begin{array}{c}\text { NR4 } \\
\text { C200-6-30-C114-3-00 }\end{array}$} & --- \\
\hline NR5 & C200-6-30-C114-3-30 & & 1.05 & & 1.19 \\
\hline NR6 & C200-6-30-C114-3-150 & & 1.11 & & 1.26 \\
\hline \multicolumn{6}{|l|}{ Series 2} \\
\hline NR7 & C200-3-150-C114-8-00 & \multirow{6}{*}{ C193.7-8-150-00 } & 0.95 & \multirow{3}{*}{$\begin{array}{l}\text { NR7 } \\
\text { C200-3-150-C114-8-00 }\end{array}$} & --- \\
\hline NR8 & C200-3-150-C114-8-30 & & 1.06 & & 1.11 \\
\hline NR9 & C200-3-150-C114-8-150 & & 1.14 & & 1.20 \\
\hline NR10 & C200-6-150-C114-3-00 & & 0.97 & \multirow{3}{*}{$\begin{array}{c}\text { NR10 } \\
\text { C200-6-150-C114-3-00 }\end{array}$} & --- \\
\hline NR11 & C200-6-150-C114-3-30 & & 1.03 & & 1.07 \\
\hline NR12 & C200-6-150-C114-3-150 & & 1.14 & & 1.11 \\
\hline
\end{tabular}




\section{LIST OF FIGURE CAPTIONS}

Fig. 1. CFDST sections: a) Double-skin b) Double-tube

Fig. 2. Room temperature tests: a) Series 1 . Outer ring C30 b) Series 2. Outer ring C150 c) CFST specimens

Fig. 3. Room temperature tests: a) Column after test b) Cross-section detail

Fig. 4. Test set-up: a) Schematic view b) Detail of the support c) Knife bearing d)Test setup at laboratory

Fig. 5. Axial load versus mid-span displacement in Series 1 (NSC outer ring).

Fig. 6. Axial load versus mid-span displacement in Series 2 (UHSC outer ring).

Fig. 7. Concrete-Steel contribution ratio

Fig. 8. Inner concrete contribution ratio

Fig. 9. Comparison between calculated buckling load (EC4) and test load

\section{LIST OF TABLE CAPTIONS}

Table 1. Details of the column specimens and test results

Table 2. Concrete-steel contribution ratio and inner concrete contribution ratio 